\title{
Allergic bronchopulmonary mycosis presenting as a new lung mass
}

\author{
Maria Landaeta, ${ }^{1}$ Macarena Vial, ${ }_{1}^{2}$ Carlos A Jimenez, ${ }^{1}$ Labib Gilles Debiane ${ }^{1}$
}

'Department of Pulmonary Medicine, The University of Texas MD Anderson Cancer Center, Houston, Texas, USA ${ }^{2}$ Pulmonary Department, Clinica Alemana de Santiago SA, Vitacura, Metropolitan Region, Chile

\section{Correspondence to}

Dr Carlos A Jimenez,

cajimenez@mdanderson.org

Accepted 29 September 2017

\section{DESCRIPTION}

A 69-year-old man with invasive pancreatic ductal adenocarcinoma underwent pancreaticoduodenectomy and adjuvant chemotherapy. Three years later, a right upper lobe (RUL) lung mass was noted on surveillance imaging, suspicious for disease recurrence. He was treated for bronchitis and remained asymptomatic 4 months later with an unremarkable physical exam. Chest imaging (figure 1A,B) showed an RUL central mass with an infiltrative pattern of growth and right paratracheal adenopathy that is negative for malignancy on endobronchial ultrasound-guided needle aspiration. Bronchoalveolar lavage and brushing grew branching septate hyphae identified as Bipolaris species. The presence of cylindrical bronchiectasis with bronchial wall thickening, mucus plugging, peripheral eosinophilia ( 810 cells $/ \mu \mathrm{L})$, elevated total serum immunoglobulin E (422.6 IU/mL) and negative aspergillus antibodies suggested allergic bronchopulmonary mycosis (ABPM) caused by Bipolaris species. After 3 months of therapy with prednisone and posaconazole, the mass-like consolidation was completely resolved (figure 1C,D).
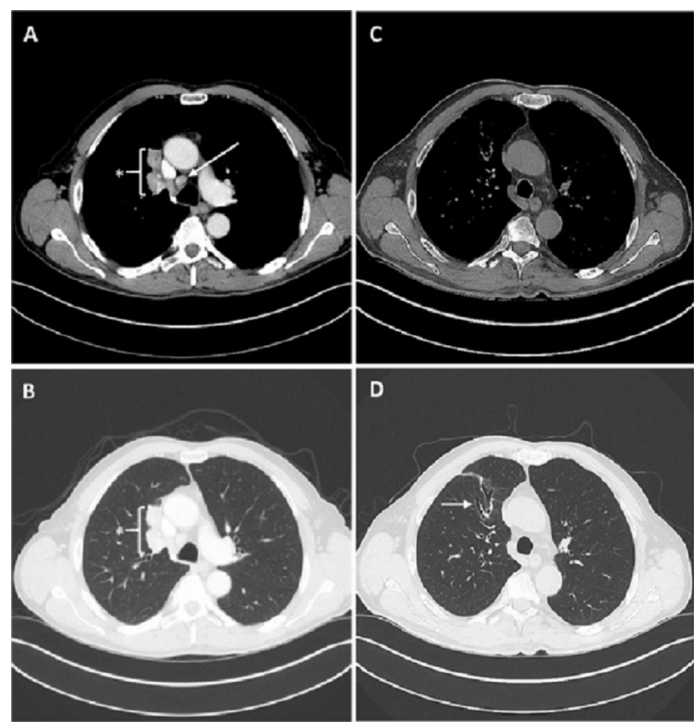

Figure 1 Chest CT scan depicting a new right upper lobe lung mass $\left({ }^{*}\right)$ with enlarged right lower paratracheal lymph node (arrow) on the mediastinal window (A) and the lung window $(B)$ views. Three months following treatment of $A B P M$, there was complete resolution of the complex right upper lobe mass (C) with evidence of mild residual bronchial wall thickening and dilatation on the lung window view (D) as part of a degree of bronchiectasis (arrow). ABPM, allergic bronchopulmonary mycosis.

\section{Learning points}

- Allergic bronchopulmonary mycosis (ABPM) can mimic metastatic lung disease in patients with previously treated solid malignancy, and high degree of clinical suspicion is needed.

- New radiological findings in patients with cancer undergoing surveillance have a broad differential diagnosis, and tissue confirmation is often needed to rule out recurrence of disease.

- ABPM diagnosis criteria include peripheral eosinophilia, cylindrical bronchiectasis with bronchial wall thickening, mucus plugging and elevated $\lg \mathrm{E}$.

$\mathrm{ABPM}$ is a pulmonary hypersensitivity disease induced by colonisation of a fungus in the airways. ${ }^{1}$ While commonly attributed to Aspergillus species, other fungi including Bipolaris have been reported to cause ABPM. ${ }^{1}$ In our case, ABPM, a rare disease, was mimicking metastaticlung disease. The approach to emerging lung masses in patients with cancer undergoing surveillance remains a challenge. While cancer recurrence is invariably the focus of attention, clinicians should be aware of the differential diagnosis for new lung masses. A primary lung malignancy should always be considered in addition to non-malignant aetiologies such as fungal and mycobacterial infections, ${ }^{2}$ radiotherapy side effects $^{3}$ and granulomatous diseases.

Contributors CAJ had the original idea to publish this interesting case, after the encounter and treating this patient at MD Anderson Cancer Center and follow his recovery (conception). $M L$ and LGD were guided by CAJ to minimise a year of patient's history in few words and selecting the best images to complete the case (reporting and planning). MV with wide experience publishing in renowned journals, edited the case before the final presentation.

Competing interests None declared.

Patient consent Obtained.

Provenance and peer review Not commissioned; externally peer reviewed.

(c) BMJ Publishing Group Ltd (unless otherwise stated in the text of the article) 2017. All rights reserved. No commercial use is permitted unless otherwise expressly granted.

\section{REFERENCES}

1 Chowdhary A, Agarwal K, Kathuria S, et al. Allergic bronchopulmonary mycosis due to fungi other than Aspergillus: a global overview. Crit Rev Microbiol 2014;40:30-48.

2 Gribetz AR, Damsker B, Bottone EJ, et al. Solitary pulmonary nodules due to nontuberculous mycobacterial infection. Am J Med 1981;70:39-43. 


\section{Images in...}

3 Choi YW, Munden RF, Erasmus JJ, et al. Effects of radiation therapy on the lung:

Copyright 2017 BMJ Publishing Group. All rights reserved. For permission to reuse any of this content visit http://group.bmj.com/group/rights-licensing/permissions.

BMJ Case Report Fellows may re-use this article for personal use and teaching without any further permission.

Become a Fellow of BMJ Case Reports today and you can:

- Submit as many cases as you like

- Enjoy fast sympathetic peer review and rapid publication of accepted articles

- Access all the published articles

- Re-use any of the published material for personal use and teaching without further permission

For information on Institutional Fellowships contact consortiasales@bmjgroup.com

Visit casereports.bmj.com for more articles like this and to become a Fellow 